DOI: https://doi.org/10.11144/Javeriana.upsy19.lspi

\title{
Longitudinal Study of the Psychological Impact of the Contingency Response to COVID-19 in Mexico*
}

\section{Estudio longitudinal del impacto psicológico de la respuesta de contingencia al COVID-19 en México}

\author{
Mónica Teresa González Ramírez \\ Universidad Autónoma de Nuevo León (UANL), México \\ ORCID: https://orcid.org/0000-0002-9058-9626 \\ Lucía Quezada Berumen $^{\text {a }}$ \\ Universidad Autónoma de Nuevo León (UANL), México \\ ORCID: https://orcid.org/0000-0003-4705-3225 \\ René Landero Hernández \\ Universidad Autónoma de Nuevo León (UANL), México \\ ORCID: https://orcid.org/0000-0002-9694-8116
}

Received: 31 August 2020 | Accepted: 26 October 2020

a Correspondence author. Email:
luciaqb86@msn.com

How to cite: González-Ramírez, M. T., QuezadaBerumen, L. Q., \& Landero Hernández, R. (2020). Longitudinal study of the psychological impact of the contingency response to COVID-19 in Mexico. Universitas Psychologica, 19, 1-10. https://doi.org/ 10.1 1144/Javeriana.upsy19.1spi

\begin{abstract}
Due to the COVID-19 pandemic, many countries have implemented prevention and care measures, among which voluntary confinement stands out. The purpose of this study was to evaluate the psychological impact of the contingency response due to COVID-19 in Mexico, considering time and level of confinement, participation in pleasurable activities during confinement, and responses derived from the economic recovery plan of the government. The study had a longitudinal design with two evaluations involving 158 people from 17 to 76 years of age who answered the questionnaires within 9 weeks. People with high confinement levels showed significant differences in positive affect, stress, and depression; people with low confinement levels and those who continued to work showed greater affection. Those who reported not having participated in pleasant activities during their confinement showed low results, and those who reported having been more worried about the economic recovery plan had a higher score in worry and a lower score in life satisfaction. It can be concluded that although psychological support interventions should focus on people in confinement, greater efforts that contribute to improving quality of life and well-being should be directed to those who work during public health contingency responses.

Keywords

COVID-19; psychological impact; lockdown; pleasant activities.
\end{abstract}

\section{RESUMEN}

Debido a la pandemia de COVID-19, muchos países han implementado medidas de prevención y atención, entre las que destaca el confinamiento voluntario. El propósito de este estudio fue evaluar el impacto psicológico de la respuesta de contingencia por COVID-19 en México, considerando tiempo y nivel de encierro, participación en actividades placenteras durante el encierro y respuestas derivadas del plan de recuperación económica del gobierno. El estudio tuvo un diseño longitudinal de dos evaluaciones en las que participaron 158 personas de 17 a 76 años que respondieron los cuestionarios en un plazo de 9 semanas. Las personas con altos niveles de confinamiento mostraron diferencias significativas 
en afecto positivo, estrés y depresión; las personas con bajos niveles de encierro y las que continuaban trabajando mostraron mayor afecto. Los que reportaron no haber participado en actividades placenteras durante su encierro mostraron peores resultados, y los que reportaron estar más preocupados por el plan de recuperación económica tuvieron mayor puntaje en preocupación y menor puntaje en satisfacción con la vida. Se puede concluir que, si bien las intervenciones de apoyo psicológico deben enfocarse en las personas confinadas, los mayores esfuerzos que contribuyan a mejorar la calidad de vida y el bienestar deben dirigirse a quienes trabajan durante las respuestas de contingencia de salud pública.

Palabras clave

COVID-19; impacto psicológico; confinamiento; actividades placenteras.

The COVID-19 pandemic has caused a series of challenges and difficulties worldwide; in most countries, people have been confined. On February 28, 2020, the first imported case of coronavirus infection was reported in Mexico. The Secretariats of Health and Public Education of the Government of Mexico implemented the prevention and care measures recommended by the Pan American Health Organization (PAHO/ WHO) against the pandemic. Therefore, nonessential school and work activities for the population were suspended, with quarantine or voluntary confinement beginning on March 23 (Secretaría de Gobernación, 2020).

Confinement is one of the international public health strategies to stop the spread of COVID-19. It consists of social isolation and voluntary sheltering of people in their homes, involving a drastic change in daily life, as well as restrictions on participation in activities outside the home, forcing citizens to implement new ways of life within the home in the face of this contingency measure (Sandín et al., 2020).

Although, in general, it represents a public good, quarantine is usually an unpleasant experience. The separation of loved ones, loss of freedom, uncertainty about the disease, and boredom can create undesirable effects. Thus, the potential benefits of mass quarantines must be carefully weighed against the possible psychological costs (Hawryluck et al., 2004; Rubin \& Wessely, 2020).
During the SARS epidemic, in people quarantined due to contact with someone potentially infected, boredom, isolation, frustration, annoyance, worry, loneliness, helplessness, anger, fear, nervousness, sadness, guilt and, to a lesser extent, happiness and relief, were reported as psychological consequences (Reynolds et al., 2008).

Brooks et al. (2020) suggest that quarantine duration is associated with worse mental health, symptoms of post-traumatic stress, avoidance behaviors, and anger. Jeong et al. (2016) documented that two-week isolation was associated with high rates of anxiety and anger symptoms. A study with hospital personnel who may have come into contact with SARS found that a 9-day quarantine was the main predictor of symptoms of acute stress disorder (Bai et al., 2004).

On the other hand, during confinement for the MERS (Middle East Respiratory Syndrome) pandemic in South Korea, the National Institute for Disaster Management (2015 in Yoon et al., 2016) found despair during the first 9 days of the outbreak, anxiety between days 15 and 19, and anger between days 20 and 31 .

In addition, confinement is an adversity of high psychosocial stress. Aspects such as the ambiguity and uncontrollability of the threat (COVID-19), the invisible and unpredictable nature of the threat, the lethality of the threat, and the possible lack of rigor of the information provided by the media can generate psychological alterations related to the perception of a threat of personal health. The worries, fears, and anxiety of confined people can also be associated with other secondary factors, such as the health of loved ones, the possible collapse of the health system, labor problems and loss of income, the global spread of the virus, and economic and social consequences of the pandemic (Sandín et al., 2020).

However, even people in confinement can be involved in rewarding tasks while concentrating on living their life as well as possible. They can, for example, continue with activities that include mentally challenging hobbies and tasks, such as solving puzzles, reading, listening to 
music, singing, playing an instrument, watching television, learning a language, playing games and even preparing for a better life change after the pandemic (Polizzi et al., 2020). Thus, according to Dekel et al. (2016), finding ways to interact and appreciate life during mass trauma is a robust predictor of increased psychological well-being and reduced posttraumatic symptoms.

The presence of COVID-19 has brought about changes and physical, psychological, and financial consequences. In this sense, on May 13, the government of Mexico presented an economic recovery plan. The reopening of some economic sectors in the country would begin on May 31, 2020, along with the consequent more significant mobilization of people in the public space. Given the increase in cases and deaths by COVID-19 in the country, greater uncertainty and worry was generated among the inhabitants; therefore, the importance of evaluating the psychological impact on people as a result of this confinement is essential for providing the necessary support and intervention tools in the most affected groups.

There is still little information available on the psychological effects of the COVID-19 pandemic (Sibley et al., 2020). In Mexico, only the study by Jaimes et al. (2020) with the general population has been identified, and there is no information on the longitudinal change in the state of mental health throughout the COVID-19 pandemic in our country. Therefore, this study constitutes an essential contribution to the Mexican and Latin American context.

The purpose of this longitudinal study was to evaluate the psychological impact of health contingency measures due to COVID-19 in Mexico, considering the time in confinement, level of confinement, participation in pleasurable activities during confinement, and responses derived from the economic recovery plan.

\section{Methods}

\section{Participants}

This longitudinal study was conducted from March 23 to 29 (first survey) and from May 18 to 25, 2020 (second survey). In the first evaluation, snowball sampling was used, focused on recruiting the general population, resulting in 673 respondents. The inclusion criteria were residents of Mexico and complete responses in both questionnaires.

For the second evaluation conducted from May 18 to 25, 158 people responded to the questionnaire. The average age was 31.8 years $(\mathrm{SD}=11.1$; range from 17 to 76 years $) ; 58.2 \%$ were single, $37.4 \%$ were married or in a free union, and the rest were divorced, separated, or widowed. A total of 103 women (65.2\%) and 55 men $(34.8 \%)$ participated; $67.1 \%$ reported not having children.

\section{Instruments}

Due to the amount of information collected, the results presented are partial. The survey used consisted of several sections; in this work, the corresponding instruments are presented.

The Positive and Negative Affect Schedule (PANAS) (Watson, Clark \& Tellegen, 1988) —adapted to Spanish by López-Gómez et al. (2015) - is composed of two subscales, i.e., positive affect (PA) and negative affect (NA), each with 10 five-point Likert-type items $(1=$ not at all or very slightly, $5=$ very much). The respondent must indicate how he or she has felt during the last week. Each subscale ranges from 10 to 50 points; a higher score indicates a greater presence of the measured affect. Cronbach's alpha coefficients for PA and NA were 0.92 and 0.88 , respectively. The coefficients for PA in the initial evaluation and the second evaluation were 0.93 and 0.95 , respectively; for NA, the coefficients were 0.93 and 0.94 .

An abbreviated version of the Depression Anxiety Stress Scales (DASS-21) (Lovibond \& Lovibond, 1995) — validated in Spanish (Daza 
et al., 2002) - is a multidimensional self-report scale designed to evaluate negative emotional states of depression, anxiety, and stress during the last week. Each dimension consists of seven Likert-type items with 0 to 3 points answered according to each symptom's presence and intensity in the last week. Each dimension ranges from 0 to 21 points. The scale has an alpha coefficient of 0.93 for depression, 0.86 for anxiety, and 0.91 for stress. The coefficients found in the initial evaluation were 0.89 for depression, 0.86 for anxiety and 0.90 for stress; in the second evaluation, the coefficients were $0.92,0.90$, and 0.93, respectively.

The Spanish adaptation of the Penn State Worry Questionnaire (PSWQ-11) (Meyer et al., 1990; Sandín et al., 2009) evaluates the degree of permanent and nonspecific worry that characterizes generalized anxiety disorder. It consists of 11 5-point Likert-type items ( $5=$ very typical of me; $1=$ not typical of me), with scores ranging from 11 to 55 . A higher score indicates a greater degree of worry. The internal consistency is 0.92 . The alpha coefficients found in the first and second evaluations were 0.96 and 0.97 , respectively.

The Satisfaction with Life Scale (SWLS) by Diener et al. (1985) -The Spanish version by Atienza et al. (2000) - has five items that evaluate an individual's overall judgment of life satisfaction. The response options range from 1 to $5(1=$ strongly disagree, $5=$ strongly agree $)$, with a final score that ranges from 1 to 25 ; a higher score indicates greater satisfaction. Cronbach's alpha is 0.84 . The reliability was 0.74 in the first evaluation and 0.91 in the second evaluation.

Additionally, the respondents were asked if they had participated in pleasant activities last week that they had not done for some time, they were asked about the effect the economic recovery plan had on them; and they were asked about their level of confinement. The levels of confinement were taken from a classification that was popularized in various media: 1) I do not take precautionary measures; I continue my normal life; 2) I take precautionary measures, but I keep going out, doing my things; 3) I go out as little as possible, but I still see friends and family; 4) I take into account all measures; I go to work and return to my house, being careful about entrances and exits; 5) I am quite isolated; I only go out if I lack food, and I limit the contact I have with other people; and 6) I am in total quarantine; no one enters or leaves my house (Grupo Fórmula, 2020).

\section{Procedure}

The Research Department approved the ethical and methodological aspects of the study. The questionnaires were disseminated through the Internet with the Google Forms survey management application. The survey was conducted online from March 23 to 29 (first survey) and from May 18 to 25, 2020 (second survey). The study's purpose and relevance were reported, and the names of those responsible and an email address to request information related to the study were provided. People answered an informed consent form before answering questionnaires. At the end of the first survey, an email address was requested, and the participants were asked to provide authorization to contact them for the follow-up study. The anonymity and confidentiality of the information provided was guaranteed at all times.

In the first evaluation, 673 people participated. Not all agreed to be contacted for the followup evaluation, and others did not respond to the invitation; therefore, the second evaluation included 158 respondents.

\section{Data analysis}

IBM $® S P S S ~ \circledR S t a t i s t i c s \quad 24$ was used. A descriptive analysis of the variables was performed. The Kolmogorov-Smirnov test indicated that the scores of all the study variables (positive affect, negative affect, depression, anxiety, stress, worry and life satisfaction) were not normally distributed $(p<0.01)$. The Kruskal-Wallis and Wilcoxon rank tests were used to identify the differences between the different study groups, with a significance level of $p<0.05$. 


\section{Results}

\section{Descriptive data}

In the second evaluation, participants reported leaving home an average of 2.6 times $(S D=2.8)$ during the last week, while in the first evaluation, the average was $2.3(\mathrm{SD}=2.6)$. When asked about their level of confinement, the majority of respondents indicated level 5 or 6 . Table 1 shows why participants left home, the most frequent being the purchase of food and basic necessities; some people in level 6 also reported visiting relatives.

\section{Table 1}

Reasons for leaving, according to level of confinement

\begin{tabular}{lrrrrr}
\hline \multicolumn{1}{c}{$\begin{array}{c}\text { Main reason for } \\
\text { leaving }\end{array}$} & \multicolumn{4}{c}{ Level of confinement } & \multirow{2}{*}{ Lotal } \\
\cline { 2 - 5 } & Level 3 & Level 4 & Level 5 & Level 6 & \\
\hline I have not gone out & 0 & 0 & 0 & 25 & 25 \\
Purchase food and & 3 & 8 & 8 & 65 & 84 \\
basic necessity items & 0 & 0 & 0 & 9 & 9 \\
Buy medications & 0 & 0 & 1 & 2 & 3 \\
Make payments & 0 & 0 & 1 & 2 & 3 \\
Walk my pet & 1 & 8 & 0 & 2 & 11 \\
Visit family members & 0 & 0 & 1 & 0 & 1 \\
Eat at restaurants & 1 & 3 & 0 & 0 & 4 \\
Clear my mind & 0 & 8 & 7 & 3 & 18 \\
Work & 5 & 27 & 18 & 108 & 158 \\
Total & & & & &
\end{tabular}

Note. Level 3) I go out as little as possible, but I still see friends and family; Level 4) I take into account all measures; I go to work and return to my house, being careful about entrances and exits; Level 5) I am quite isolated; I only go out if I lack food, and I limit the contact I have with other people; and Level 6) I am in total quarantine; no one enters or leaves my house.

Most of the participants began their isolation the first week the confinement measures were released (between March 17 and 23), having 9 weeks in confinement by the day they responded to the second evaluation (Table 2).
Table 2

Start date and level of confinement

\begin{tabular}{lrrrrr}
\hline \multirow{2}{*}{ Start date of confinement } & \multicolumn{4}{c}{ Level of confinement } & \multirow{2}{*}{ Total } \\
\cline { 2 - 5 } & Level 3 & Level 4 & Level 5 & Level 6 & \\
\hline Between March 17th and 23rd & 4 & 17 & 6 & 90 & 117 \\
Between March 24th and 31st & 1 & 3 & 12 & 12 & 28 \\
Between April 1st and 15th & 0 & 0 & 0 & 4 & 4 \\
After May 1st & 0 & 0 & 0 & 1 & 1 \\
Continued to work & 0 & 7 & 0 & 0 & 7 \\
Total & 5 & 27 & 18 & 107 & $157^{*}$ \\
\hline
\end{tabular}

Note. *A person did not indicate the start date of confinement. Level 3) I go out as little as possible, but I still see friends and family; Level 4) I take into account all measures; I go to work and return to my house, being careful about entrances and exits; Level 5) I am quite isolated; I only go out if I lack food, and I limit the contact I have with other people; and Level 6) I am in total quarantine; no one enters or leaves my house.

Differences between the first and second evaluations

When evaluating the differences between the two evaluations over 9 weeks $(\mathrm{n}=158)$, a significant increase in depression, anxiety, and stress scores was observed. A decrease in positive affect was also observed (Table 3).

Table 3

Change in psychological variables

\begin{tabular}{|c|c|c|c|c|}
\hline Psychological variable & M & Average & SD & Mann-Whitney's U \\
\hline Positive affect (Initial) & 33.0 & 32.2 & 8.4 & \multirow{2}{*}{$Z=-4.186(p=0.001)$} \\
\hline Positive affect (Final) & 30.0 & 29.1 & 8.7 & \\
\hline Negative affect (Initial) & 18.0 & 20.1 & 8.6 & \multirow{2}{*}{$Z=-0.644(p=0.519)$} \\
\hline Negative affect (Final) & 18.0 & 21.3 & 9.9 & \\
\hline DASS depression (Initial) & 2.0 & 3.3 & 4.2 & \multirow{2}{*}{$\mathrm{Z}=-3.073(p=0.002)$} \\
\hline DASS depression (Final) & 3.0 & 4.5 & 4.8 & \\
\hline DASS anxiety (Initial) & 1.0 & 2.7 & 3.6 & \multirow{2}{*}{$Z=-2.161(p=0.031)$} \\
\hline DASS anxiety (Final) & 2.0 & 3.5 & 4.4 & \\
\hline DASS stress (Initial) & 4.0 & 4.9 & 4.6 & \multirow{2}{*}{$Z=-2.632 \quad(p=0.008)$} \\
\hline DASS stress (Final) & 4.5 & 6.1 & 5.5 & \\
\hline Worry (Initi & 25.0 & 28.5 & 12.2 & \multirow{2}{*}{$Z=-0.645(p=0.519)$} \\
\hline Worry (Final) & 27.0 & 29.4 & 14.1 & \\
\hline Life satisfaction (Initial) & 18.0 & 17.6 & 4.0 & \multirow{2}{*}{$Z=-1.585(p=0.113)$} \\
\hline Life satisfaction (Final) & 18.0 & 17.1 & 5.0 & \\
\hline
\end{tabular}

Differences according to the level of confinement

When evaluating the differences according to the confinement level, people who indicated level 6 confinement exhibited a significant increase in depression scores, while people who indicated level 5 confinement had significantly increased stress scores. Positive affect decreased significantly in people with levels 5 and 6 confinement. Those people who indicated level 
4 confinement (who currently go out to work) showed decreased positive affect and increased negative affect, depression, anxiety, stress and worry.

\section{Table 4}

Psychological impact according to the level of isolation

\begin{tabular}{|c|c|c|c|c|c|c|c|}
\hline $\begin{array}{l}\text { solation } \\
\text { level }\end{array}$ & $\begin{array}{l}\text { Positive } \\
\text { affect }\end{array}$ & $\begin{array}{c}\text { Negative } \\
\text { affect }\end{array}$ & $\begin{array}{c}\text { DASS } \\
\text { depression }\end{array}$ & $\begin{array}{c}\text { DASS } \\
\text { anxiety }\end{array}$ & DASS stress & Worr & $\begin{array}{c}\text { Life } \\
\text { satisfactic }\end{array}$ \\
\hline & I: $32.2(14$. & $25.8(10.9)$ & 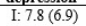 & I: $5.6(4.4)$ & (6.2) & I: & \\
\hline Level & & $\begin{array}{r}\mathrm{F}: 21 \\
\mathrm{Z} \\
(p=\end{array}$ & $\begin{array}{l}\mathrm{F}: 2 . \\
Z= \\
(p=\end{array}$ & $\begin{array}{r}\mathrm{F}: 5.0(3.4) \\
\mathrm{Z}=0 \\
(p=1.0\end{array}$ & & & \\
\hline & & I: 1 & & $\mathrm{I}: 2.1$ & & & \\
\hline $\begin{array}{l}\text { Level } \\
(\mathrm{n}=27\end{array}$ & & $\begin{array}{r}\mathrm{F}: 26 . \\
\mathrm{Z}=\end{array}$ & & $\begin{array}{l}\mathrm{F}: 5.8 \\
Z=\end{array}$ & & & \\
\hline & & & & & & & \\
\hline & & & & & & & \\
\hline & & & & & & & \\
\hline & & & & & & & \\
\hline 10 & $\begin{array}{r}\text { I: } 32 . \\
\mathrm{F}: 29 . \\
\mathrm{Z}=\end{array}$ & $\begin{array}{r}\text { I: } 20 . \\
\text { F: } 20 . \\
Z=\end{array}$ & $\begin{array}{l}\text { I: } 3.1 \\
\text { F: } 4.2 \\
Z=.\end{array}$ & $Z=$ & & $\begin{array}{l}\text { I: } 28 \\
\text { F: } 27 \\
Z\end{array}$ & $\begin{array}{l}\text { I: } 18 \\
\mathrm{~F}: 17 \\
\mathrm{Z}\end{array}$ \\
\hline & & & & & & & \\
\hline
\end{tabular}

Note. The mean and standard deviation are shown in parentheses. I = initial evaluation; $\mathrm{F}$ = final evaluation. Level 3) I go out as little as possible, but I still see friends and family; Level 4) I take into account all measures; I go to work and return to my house, being careful about entrances and exits; Level 5) I am quite isolated; I only go out if I lack food, and I limit the contact I have with other people; and Level 6) I am in total quarantine; no one enters or leaves my house

Differences according to the start date of isolation

Differences were analyzed considering the date on which the participants began their confinement. Because there were no significant differences between the initial and final evaluations in those who started isolation between April 1 and 15 (4 people) and after May 1 (one person), this information was not added to the table (Table 5); one person did not indicate the date on which he/she began isolation.

In people who reported having been in confinement for 9 weeks (between March 17 and 23), depression increased significantly. Positive affect decreased, which occurred in people who began isolation one week later (from March 24 to 31). Notably, although only seven people classified themselves as "I am not in isolation; I continue going to work," significant differences were found in all variables, except for depression and worry, in which there was great variability when considering the standard deviation of the second measurement, which reflects extreme cases.

Table 5

Psychological impact according to time in confinement

\begin{tabular}{|c|c|c|c|c|c|c|c|}
\hline $\begin{array}{c}\text { Isolation } \\
\text { start } \\
\text { date } \\
\end{array}$ & $\begin{array}{c}\text { Positive } \\
\text { affect }\end{array}$ & $\begin{array}{c}\text { Negative } \\
\text { affect }\end{array}$ & $\begin{array}{c}\text { DASS } \\
\text { depression }\end{array}$ & $\begin{array}{c}\text { DASS } \\
\text { anxiety }\end{array}$ & DASS stress & Wo & $\begin{array}{c}\text { Satisfaction } \\
\text { vital }\end{array}$ \\
\hline Between & I: $31.7(8.2)$ & I: $21.4(9.3)$ & I: $3.7(4.2)$ & I: $3.1(3.9)$ & I: 5.6 & I: 30.0 & I: $17.6(4.2)$ \\
\hline $\begin{array}{l}\text { March } 17 \\
\text { and 23 }\end{array}$ & $\mathrm{F}: 29$ & $\begin{array}{c}\mathrm{F}: 21 \\
\mathrm{Z}=\end{array}$ & & & & & 5.1) \\
\hline 23 & & & & & & & z \\
\hline$\frac{(11=11)}{\text { Between }}$ & $\begin{array}{r}p=0.00 \\
\mathrm{I}: 35.3(8\end{array}$ & $\begin{array}{c}(p=0.104) \\
\mathrm{I}: 15.8(4.1)\end{array}$ & $\begin{array}{l}(p=0.001) \\
\mathrm{I}: 2.2(3.6)\end{array}$ & $\frac{D=0}{\mathrm{I}: 1.8}$ & $\frac{w p=0}{\mathrm{I}: 3.1}$ & $\begin{array}{l}(p=0 \\
\mathrm{I}: 21.6\end{array}$ & $\begin{array}{l}(p=.0 .82) \\
\text { I: } 17.6(4.2)\end{array}$ \\
\hline $\begin{array}{l}\text { March } 24 \\
\text { and } 31\end{array}$ & $\begin{array}{r}\mathrm{F}: 30.8(7.8) \\
Z=-2.697\end{array}$ & $\begin{aligned} F: 18.1(7.8) \\
Z=-0.924\end{aligned}$ & $\begin{array}{l}\mathrm{F}: 2.6(3.4) \\
Z=-0.752\end{array}$ & $\begin{array}{l}F: 2.0(2.6) \\
Z=-0.049\end{array}$ & $\begin{array}{c}\text { F: } 5.1(5.1) \\
Z=-1.986\end{array}$ & $\begin{array}{r}\mathrm{F} \cdot 23.6(9.7) \\
\mathrm{Z}=-1.299\end{array}$ & $\begin{array}{r}\mathrm{F}: 17.2(5.1) \\
\mathrm{Z}=-1.204\end{array}$ \\
\hline$(\mathrm{n}=28)$ & & & $(p=0.4$ & & & & \\
\hline tinue & I: 32.0 .3 & I: 16. & I: 1.8 & I: 0.6 & I: 1.9 & I: 25 & F. \\
\hline & $\begin{array}{rl}F & 21.1(3.9) \\
Z & =-2388\end{array}$ & $\mathrm{~F}: 30.9(11.8)$ & $\begin{array}{rl}F & 6.0(4.9) \\
Z & =-0.957\end{array}$ & F: 7.1 (3.9) & F: $10.0(5.6)$ & F: $\begin{array}{ll}37.7(16.3) \\
Z=-1023\end{array}$ & $\begin{aligned} F & =10.6(3.6) \\
Z & =-2.280\end{aligned}$ \\
\hline & $\begin{aligned} 2 & =-2.388 \\
(p & =0.017)\end{aligned}$ & $\begin{aligned} Z & =-2.047 \\
(p & =0.041)\end{aligned}$ & $\begin{aligned} Z & =-0.95) \\
(p & =0.339)\end{aligned}$ & $\begin{array}{l}Z=-2.2177 \\
(p=0.027)\end{array}$ & $\begin{aligned} 2 & =-2.232 \\
(p & =0.026)\end{aligned}$ & $\begin{array}{l}Z=-1.023 \\
(p=0306\end{array}$ & $\begin{aligned} 2 & =-2.280 \\
(p & =0.023)\end{aligned}$ \\
\hline
\end{tabular}

Note. The mean and standard deviation are shown in parentheses. I = initial evaluation; F = final evaluation. Level 3) I go out as little as possible, but I still see friends and family; Level 4) I take into account all measures; I go to work and return to my house, being careful about entrances and exits; Level 5) I am quite isolated; I only go out if I lack food, and I limit the contact I have with other people; and Level 6) I am in total quarantine; no one enters or leaves my house.

\section{Pleasant activities during confinement and reaction to economic reactivation}

The initial and final scores were compared between those who reported having participated in pleasant activities within the last week that they had not done in a long time $(\mathrm{n}=116)$ and those who answered no $(n=42)$. In the group that participated in pleasant activities, only a significant decrease in positive affect was found $(Z=-3.105 ; p=0.002)$, and the other variables were equivalent in the two evaluations $(p>0.05)$. The group that reported not participating in pleasant activities showed significant differences in all variables $(p<$ $0.05)$, with a decrease in positive affect and life satisfaction and an increase in negative affect, depression, stress, anxiety, and worry.

Finally, reactions upon knowing of the economic recovery plan were obtained. Eightynine people indicated that they worried more, 39 indicated that they did not know, or the news had no effect on them, and 30 mentioned that they calmed down. When comparing the three groups, differences were found in worry $(\mathrm{Z}=$ 9.582; $p=0.008)$ and life satisfaction $(Z=$ 
$6.435 ; p=0.040$ ); the group that reported having been more worried about economic reactivation showed higher scores for worry and lower scores for life satisfaction.

\section{Discussion}

The purpose of this study was to analyze the change in some psychological variables after 9 weeks ( 2 months) of initiation of confinement in Mexico as a preventive measure of propagation before the COVID-19 pandemic.

When considering the complete sample, an increase in depression, anxiety, and stress was found, and a decrease in positive affect was found. This supports the findings of a review by Brooks et al. (2020). Most of the studies reported adverse psychological effects due to the quarantine, including post-traumatic stress, confusion and anger. Similarly, the results agree with a cross-sectional study by Qiu et al. (2020) in China, where high levels of anxiety and depression are reported due to the COVID-19 pandemic.

Regarding the worry variable, when dividing the sample according to the confinement level, an increase was detected in people who indicated level 4 confinement, i.e., those who leave the house to work. This group also exhibited increases in negative affect, depression, stress, and anxiety and a decrease in positive affect.

While people who indicated higher levels of confinement had a less positive affect and greater depressive symptoms (people who indicated level 6 confinement) and stress (people who indicated level 5 confinement), people who left their house to work (level 4) were the most affected. Confinement has been described as an event that produces discomfort (Hawryluck et al., 2004; Rubin \& Wessely, 2020); however, our results suggest that not being able to take shelter due to work generates greater discomfort than that experienced by confined people. In this sense, it can be assumed that constant exposure to risky situations can result in highly stressful experiences, which affect emotional and psychological responses, as well as the life satisfaction of the people who work, which puts their well-being at risk.

Brooks et al. (2020) reported that the stressors reported due to quarantine are duration, fear of infection, frustration, boredom, lack of supplies, inadequate information, financial problems, and stigma. In our study, the group that exhibited significantly increased depression scores indicated that they were in total isolation (level 6), i.e., those who have the least contact with others, which could influence the increase in depressive symptoms. For the above, people with higher levels of confinement (levels 5 and 6) also face stressors, although different from people who indicated level 4 confinement, which explains the results.

The duration of the isolation is considered a stressor (Brooks et al., 2020). In Spain, OzamizEtxebarria et al. (2020) reported an increase in symptoms of stress, depression, and anxiety after quarantine. In New Zealand, Sibley et al. (2020), in a longitudinal study with a large sample formed by different people in two evaluations, found no change in life satisfaction but an increase in stress 18 days after quarantine. These results partially coincide with the findings of the present study.

Our results indicate that although people with more time in confinement (between 9 and 8 weeks at the time of evaluation) reported a decrease in positive affect and an increase in symptoms of depression (people in confinement for 9 weeks), people who continued to work showed a significant increase in negative affect, stress, and anxiety and a decrease in positive affect and life satisfaction. Among the people who continued working were health sector personnel. In this sense, during the COVID-19 pandemic, medical workers in Wuhan faced stressors, such as high risk and inadequate protection against infection, overwork, frustration, discrimination, isolation, patients with negative emotions, lack of contact with their families, and exhaustion (Kang et al., 2020), which, according to Jones et al. (2017), causes mental health problems such as stress, anxiety, depressive symptoms, insomnia, denial, anger, and fear. These mental health problems 
could have lasting effects on their general wellbeing (Kang et al., 2020).

A possible protective factor is participating in pleasant activities during confinement. We found that people who reported not participating in this type of activity had study variables that worsened significantly. From the above, it can be assumed that the types of activities people perform during confinement have a significant impact on their mental health (Dekel et al., 2016; Polizzi et al., 2020). In this sense, it is recommended that people take up personal hobbies that they can perform at home or any activity that they consider pleasant and that allows maintaining a physical distance to continue prevention measures against COVID-19.

The news of the recovery of the economy in Mexico was cause for controversy and uncertainty and, according to our results, of worry in the participants, with the most worried being those who showed significantly lower scores for life satisfaction. In this sense, Sandín et al. (2020) proposed that the accumulation of stressful events such as contingency measures, the threat of the virus, confinement, work problems, loss of income, and fear and worry for their own health and that of loved ones are factors that affect the well-being of people, impacting life satisfaction.

To our knowledge, this is the first longitudinal study that evaluates the same people at two months of confinement, representing a critical challenge that brought several limitations. The sample size is the first limitation of the study. At the time of the first evaluation, the dissemination of questionnaires from other studies was not detected in social networks. However, at the time of requesting the second response, there were a lot of online questionnaires; therefore, we assume that there were excess stimuli for the participants. Other limitations include nonprobabilistic sampling and the lack of representativeness of the sample (most of the participants were residents of the north and center of the country); therefore, the data's generalization is not possible. Finally, by not considering the occupation of people as a study variable, we do not know if the people who worked despite the health contingency measures correspond to personnel in charge of activities essential to the population or to health personnel, which constitutes an area of opportunity for future studies conducted in Mexico.

Despite the limitations, this study constitutes a significant contribution, as it is one of the first longitudinal studies conducted in Mexico. Thus, we can argue that, although psychological support interventions should continue to focus on people in confinement, greater efforts should be directed toward those people who work despite health contingency measures, considering individual, labor, and social aspects, which would improve their quality of life and well-being.

\section{References}

Atienza, F. L., Pons, D., Balaguer, I., \& Merita, M. G. (2000). Propiedades psicométricas de la Escala de Satisfacción con la Vida en adolescentes. Psicothema, 12(2), 314-319. http://www.psicothema.com/psic othema.asp? $\mathrm{id}=296$

Bai, Y., Lin, C. C., Lin, C. Y., Chen, J. Y., Chue, C. M., \& Chou, P. (2004). Survey of stress reactions among health care workers involved with the SARS outbreak. Psychiatric Services, 55(9), 1055-1057. https ://doi.org/10.1176/appi.ps.55.9.1055

Brooks, S. K., Webster, R. K., Smith, L. E., Woodland, L., Wessely, S., Greenberg, N., \& Rubin, G. J. (2020). The psychological impact of quarantine and how to reduce it: rapid review of the evidence. The Lancet, 395, 912-920. https://doi.org/10.1016/S014 0-6736(20)30460-8

Daza, P., Novy, D. M., Stanley, M. A., \& Averill, P. (2002). The depression anxiety stress scale-21: Spanish translation and validation with a Hispanic sample. Journal of Psychopathology and Behavioral Assessment, 24(3), 195-205. https://doi.org/ 10.1023/A:1016014818163 
Dekel, S., Hankin, I. T., Pratt, J. A., Hackler, D. R., \& Lanman, O. N. (2016). Posttraumatic growth in trauma recollections of $9 / 11$ survivors: A narrative approach. Journal of Loss and Trauma, 21(4), 315-324. https://d oi.org/10.1080/15325024.2015.1108791

Diener, E., Emmons, R., Larsen, R. J., \& Griffin, S. (1985). The Satisfaction with Life Scale. Journal of Personality Assessment, 49(1), 71-75. https://doi.org/10.1207/s15327752j pa4901_13

Grupo Fórmula (2020, April 1). Del 1 al 6: ¿En qué nivel de aislamiento estás? El gráfico que se hizo viral. https://www.radioformula.com.mx/en tretenimiento/20200401/cuarentena-aisla miento-coronavirus-covid-19-en-que-nivel -estas-grafico/amp/

Hawryluck, L., Gold, W. L., Robinson, S., Pogorski, S., Galea, S., \& Styra, R. (2004). SARS control and psychological effects of quarantine, Toronto, Canada. Emerging Infectious Diseases, 10(7), 1206. https://doi. org/10.3201/eid1007.030703

Jaimes, N. L. G., Alcántara, A. A. T., Méndez, C. M., \& Hernández, Z. O. O. (2020). Impacto psicológico en estudiantes universitarios mexicanos por confinamiento durante la pandemia por Covid-19. Scielo Preprints. ht tps://doi.org/10.1590/SciELOPreprints.756

Jeong, H., Yim, H. W., Song, Y. J., Ki, M., Min, J. A., Cho, J., \& Chae, J. H. (2016). Mental health status of people isolated due to Middle East Respiratory Syndrome. Epidemiology and Health, 38, e2016048. htt ps://doi.org/10.4178/epih.e2016048

Jones, N. M., Thompson, R. R., Dunkel Schetter, C., \& Silver, R. C. (2017). Distress and rumor exposure on social media during a campus lockdown. Proceedings of the National Academy of Sciences of the United States of America, 114,11663-11668. https:/ /doi.org/10.1073/pnas.1708518114

Kang, L., Li, Y., Hu, S., Chen, M., Yang, C., \& Yang, B. (2020). The mental health of medical workers in Wuhan, China dealing with the 2019 novel coronavirus. The
Lancet Psychiatry, 7(3), E14. https://doi.org/ 10.1016/S2215-0366(20)30047-X

López-Gómez, I., Hervas, G., \& Vázquez, C. (2015). Adaptación de la "Escala de afecto positivo y negativo" (PANAS) en una muestra general española. Psicología Conductual, 23(3), 529-548.

Lovibond, S. H., \& Lovibond, P. F. (1995). Depression Anxiety and Stress Scales (DASS-42). Sydney: Psychology Foundation. https://doi.org/10.1037/t3983 $5-000$

Meyer, T. J., Miller, M. L., Metzger, R. L., \& Borkovec, T. D. (1990). Development and validation of the Penn StateWorry Questionnaire. Behaviour Research and Therapy, 28, 487-495. https://doi.org/10.10 16/0005-7967(90)90135-6

Ozamiz-Etxebarria, N., Dosil-Santamaria, M., Picaza-Gorrochategui, M., \& IdoiagaMondragon, N. (2020). Niveles de estrés, ansiedad y depresión en la primera fase del brote del COVID-19 en una muestra recogida en el norte de España [Stress, anxiety, and depression levels in the initial stage of the COVID-19 outbreak in a population sample in the northern Spain]. Cadernos de Saúde Pública, 36(4), e00054020. https://doi.org/10.1590/0102-3 $11 \times 00054020$

Polizzi, C., Lynn, S. J., \& Perry, A. (2020). Stress and Coping in the time of COVID-19: Pathways to resilience and recovery. Clinical Neuropsychiatry, 17(2), 59-62. https://doi.o $\mathrm{rg} / 10.36131 / \mathrm{CN} 20200204$

Qiu, J., Shen, B., Zhao, M., Wang, Z., Xie, B., \& Xu, Y. (2020). A nationwide survey of psychological distress among Chinese people in the COVID-19 epidemic: implications and policy recommendations. General Psychiatry, 33, e100213. https://doi .org/10.1136/gpsych-2020-100213

Reynolds, D. L., Garay, J. R., Deamond, S. L., Moran, M. K., Gold, W., \& Styra, R. (2008). Understanding, compliance and psychological impact of the SARS quarantine experience. Epidemiology $\mathfrak{G}$ 
Infection, 136(7), 997-1007. https://doi.org/ $10.1017 /$ S0950268807009156

Rubin, G. J., \& Wessely, S. (2020). The psychological effects of quarantining a city. BMJ, 368. https://doi.org/10.1136/bmj.m31 3

Sandín, B., Chorot, P., Valiente, R. M., \& Lostao, L. (2009). Validación española del cuestionario de preocupación PSWQ: Estructura factorial y propiedades psicométricas. Revista de Psicopatología y Psicología Clínica, 14(2), 107-122. https://doi.org/10.5944/rppc.vol.1 4.num.2.2009.4070

Sandín, B., Valiente, R. M., García-Escalera, J., \& Chorot, P. (2020). Impacto psicológico de la pandemia de COVID-19: Efectos negativos y positivos en población española asociados al periodo de confinamiento nacional. Revista de Psicopatologia y Psicologia Clinica, 25(1), 1-22. https://doi.org/10.5944/rppc.2 7569

Secretaría de Gobernación (2020). ACUERDO por el cual se modifica y adiciona el diverso ACT-EXT PUB/20/03/2020.02 en el sentido de suspender provisionalmente las sesiones del Pleno de este Instituto en concordancia con el Acuerdo por el que se establecen las medidas preventivas que se deberán implementar para la mitigación y control de los riesgos para la salud que implica la enfermedad por el virus SARS. CoV2 (COVID-19), de la Secretaría de Salud, publicado en la edición vespertina de 24 de marzo de dos mil veinte. DOF: 31/03/2020. http://www.dof.gob.mx/nota detalle.php?codigo $=5590793 \&$ fecha $=31 /$ 03/2020\&print $=$ true

Sibley, C. G., Greaves, L. M., Satherley, N., Wilson, M. S., Overall, N. C., Lee, C. H., Milojev, P., Bulbulia J., Osborne, D., Milfont, T. L., Houkamau, C. A., Duck, I. M., Vickers-Jones, R., \& Barlow F. K. (2020). Effects of the COVID-19 pandemic and nationwide lockdown on trust, attitudes toward government, and well-being. American Psychologist, 75(5),
618-630. https://doi.org/10.1037/amp0000 662

Watson, D., Clark, L. A., \& Tellegen, A. (1988). Development and validation of brief measures of positive and negative affect: the PANAS scales. Journal of Personality and Social Psychology, 54(6), 1063-1070. https://doi.org/10.1037//00223514.54.6.1063

Yoon, M. K., Kim, S. Y., Ko, H. S., \& Lee, M. S. (2016). System effectiveness of detection, brief intervention and refer to treatment for the people with posttraumatic emotional distress by MERS: a case report of community-based proactive intervention in South Korea. International Journal of Mental Health Systems, 10(1). htt ps://doi.org/10.1186/s13033-016-0083-5

\section{Notes}

* Research article 